\title{
KEMANDIRIAN PENGADILAN TINDAK PIDANA KORUPSI DALAM SISTEM KETATANEGARAAN DI INDONESIA
}

\author{
M. Agus Santoso \\ Fakultas Hukum Universitas Widya Gama Mahakan Samarinda \\ E-mail: agus.santoso@yahoo.com
}

\begin{abstract}
Purpose of this study is to find out the independence of the judiciary of corruption in the state system in Indonesia. The method used is a normative legal research methods (legal research), with the approach of the statute .Data sourced from legislation, library materials, and interviews. Qualitative data was analyzed in such a way and set out in writing a descriptive analysis. The results of this study illustrate that the independence of the corruption judiciary is determined from the independence of its institutions, the courts, and the judges. The intervention against corruption court decision is not aimed at her agency or the judicial process, but addressed to the judge overseeing the corruption case, in the form of feedback, criticism and even censure which was published in a newspaper that has led to contempt of court.
\end{abstract}

Key words: Independence of corruption court, and constitutional system.

\begin{abstract}
Abstrak
Tujuan Penelitian ini ialah untuk mengetahui kemandirian pengadilan tindak pidana korupsi dalam sistem ketatanegaraan di Indonesia. Metode yang digunakan ialah metode penelitian hukum normatif (legal research), dengan pendekatan perundang-undangan (Statute approach) .. Data yang bersumber dari perundang-undangan, bahan pustaka, dan hasil wawancara. Data kualitatif kemudian dianalisis sedemikian rupa dan dituangkan dalam bentuk tulisan secara diskriptif analisis. Hasil penelitian ini memberi gambaran bahwa bentuk kemandirian pengadilan tindak pidana korupsi ditentukan dari kemandirian lembaganya, proses peradilannya, dan hakimnya. Adanya intervensi terhadap putusan pengadilan tindak pidana korupsi bukan ditujukan terhadap lembaganya atau proses peradilannya, tetapi ditujukan kepada hakim yang menangani perkara korupsi, berupa tanggapan, kritik dan bahkan celaan yang dimuat dalam berita surat kabar yang sudah mengarah pada contempt of court.
\end{abstract}

Kata kunci: Kemandirian Pengadilan Tipikor, dan sistem ketatanegaraan.

\section{A. Pendahuluan}

Indonesia adalah negara hukum yang bertujuan melindungi segenap bangsa Indonesia dan seluruh tumpah darah Indonesia, mewujudkan kehidupan masyarakat bangsa dan negara yang sejahtera, tertib aman, damai dan sentausa, serta berkeadilan,sosial seperti yang diamanatkan dalam alinea ke empat pembukaan Undang-Undang Dasar 1945. Konsekuensi negara hukum adalah negara harus menempatkan hukum sebagai panglimanya serta menjadikan hukum sebagai alat untuk menyelesaikan segala permasalahan.termasuk dalam upaya pemberantasan tindak pidana korupsi.

Tindak pidana korupsi harus dipandang sebagai kejahatan luar biasa (extra ordinary crime). Selama ini tindak pidana korupsi telah menimbulkan kerusakan dalam berbagai sendi kehidupan masyarakat, bangsa dan negara, oleh karena itu pemberantasan tindak pidana korupsi harus dilakukan secara terus menerus dan berkesinambungan serta menuntut kapasitas sumber daya manusia yang baik maupun adanya kelembagaan, baik lembaga penuntutan maupun lembaga peradilannya yang khusus memeriksa, mengadili dan memutus perkara tindak pidana korupsi sesuai dengan sistem hukum nasional di Indonesia. Sudah dapat dipastikan bahwa tindak pidana korupsi akan merugikan keuangan negara dan bahkan perekonomian nasional sehingga masyarakat dan negara banyak dirugikan serta berimbas pada terhambatnya pembangunan nasional. Oleh karena itu, harus diberantas dalam rangka mewujudkan masyarakan yang adil dan makmur berdasarkan Pancasila dan Undang-Undang Dasar 1945, serta mengembangkan sikap dan perilaku agar masyarakan tidak melakukan korupsi dan bahkan sikap dan perilaku masyararat anti korupsi yang kemudian dituangkan dalam sistem hukum nasional.

Tindak pidana korupsi saat ini merupakan persoalan mendasar, bukan saja persoalan lokal tetapi sudah menjadi persoalan nasional dan bahkan internasional. Dalam upaya pemberantasan tindak pidana korupsi, saat ini bangsa Indonesia telah ikut 
aktif dalam upaya masyarakat internasional untuk pencegahan dan pemeberantasan tindak pidana korupsi, yaitu dengan telah ikut menandatangani United Nations Convention Against Corruption, 2003 (Konvensi Perserikatan Bangsa-Bangsa Anti Korupsi, 2003), yang telah diratifikasi dan disahkan dengan Undang-Undang Nomor 7 Tahun 2006, tentang Pengesahan United Nations Convention Against Corruption, 2003 (Konvensi Perserikatan Bangsa-Bangsa Anti Korupsi 2003). Bagian penting isi pokok Konvensi Perserikatan Bangsa-Bangsa Anti Korupsi tersebut adalah mengenai pencegahan dan penegakkan hukum tindak pidana korupsi, termasuk penyuapan pejabat publik, penggelapan, penyalahgunaan wewenang atau penyimpangan lain kekayaan oleh pejabat public (M. Agus Santoso, 2011: 137). Salah satu bentuk upaya penegakkan hukum tindak pidana korupsi yang dilakukan Indonesia adalah dengan membentuk pengadilan tindak pidana korupsi yang selanjutnya disebut pengadilan tipikor berdasarkan Undang-Undang Nomor 46 Tahun 2009, tentang Pengadilan Tindak Pidana Korupsi (TIPIKOR).

Keberadaan pengadilan tipikor semula didasari oleh Pasal 53 Undang-Undang Nomor 39 Tahun 2002, tentang Komisi Pemberantasan Tindak Pidana Korupsi, kemudian berdasarkan putusan Mahkamah Konstitusi Republik Indonesia dinyatakan bertentangan dengan Undang-Undang Dasar 1945, sehingga harus dibentuk UndangUndang yang baru, yaitu Undang-Undang Nomor 46 Tahun 2009 tentang Pengadilan Tindak Pidana Korupsi (TIPIKOR), yang merupakan pengadilan khusus dan satu-satunya pengadilan yang berwenang memeriksa, mengadili, dan memutus perkara tindak pidana korupsi.

Pengadilan tipikor merupakan pengadilan khusus yang berada di lingkungan Peradilan Umum, berkedudukan di setiap ibu kota kabupaten/kota yang daerah hukumnya meliputi daerah hukum pengadilan negeri yang bersangkutan. Dalam perjalanan berlakunya pengadilan tipikor, untuk pertama kali dibentuk pada setiap Pengadilan Negeri di ibu kota provinsi, yang daerah hukumnya meliputi daerah hukum provinsi bersangkutan, kini telah diberlakukan secara devinitif dan serentak di seluruh Indonesia sejak tanggal 28 Mei 2011. Upaya pembentukan pengadilan tipikor ternyata membawa dapak yang begitu besar, walaupun belum ada satu tahun berdirinya pengadilan tipikor ternyata kasus korupsi yang ditangani cukup banyak. Tercatat sebagai contoh sepanjang tahun 2011 Pengadilan Tipikor Samarinda telah menangani perkara sebanyak 45 kasus korupsi, hal ini menunjukkan begitu seriusnya pemberantasan tindak pidana korupsi di Indonesia. Jika pada era orde baru hampir tidak kedengaran kasus korupsi bukan berarti tidak ada perkara korupsi tetapi lebih kepada bahwa penanganannya yang belum optimal. Dari total 45 perkara korupsi yang masuk di Pengadilan Tipikor Samarinda, telah memutuskan 19 perkara korupsi dengan jumlah terdakwa 21 orang, artinya belum cukup satu tahun berdirinya pengadilan tindak pidana korupsi sudah dapat memeriksa dan mengadili serta memutus perkara sebanyak itu. Dari total perkara yang telah diputus oleh pengadilan tipikor ternyata tidak semuanya dijatuhi hukuman, karena dari 21 orang tedakwa hanya 5 orang yang dijatuhi hukuman sedangkan 16 orang terdakwa di vonis bebas atau onslag van recht vervolging (putusan bebas dari segala tuntutan hukum), (Berita Kaltim Pos, 1 Nopember 2011), akhirnya Jaksa Penunutut Umum mengajukan kasasi ke Mahkamah Agung Republik Indonesia.

Vonis bebas perkara korupsi di Pengadilan Tipikor Samarinda tersebut mendapat reaksi keras dari berbagai pihak, hampir semua media massa menyorotinya dengan argumentasi bahwa dalam sejarah pembentukan Komisi Pemberantasan Korupsi (KPK), tidak pernah terjadi seorang terdakwa lolos dari jeratan hukum, sekali menjadi tersangka maka dipastikan bakal dihukum masuk penjara. Semua mata memandang sinis putusan bebas tersebut, termasuk Lembaga Swadaya Masyarakat (LSM), kalangan akademisi, dan bahkan Mahfud MD, Ketua Mahkamah Konstitusi mengeluarkan pendapat pribadinya :"Bubarkan saja pengadilan tipikor di daerah." (Majalah B Magazine, edisi Desember 2011).

Langkah untuk melemahkan putusan bebas majelis hakim, sejumlah penggiat anti korupsi di Kalimantan Timur menduga lemahnya dakwaan Jaksa Penuntut Umum, sehingga kemudian berupaya dan mendesak Kajaksaan Tinggi Kalimantan Timur untuk memeriksa Jaksa yang menangani kasus korupsi tersebut, bahkan upaya lain dilakukan juga dengan menyurati Mahkamah Agung (MA) dan Komisi Yudisial (KY), agar Mahkamah Agung turun tangan untuk mengkroscek para hakim tipikor yang bertugas di daerah (Berita Tribun Kaltim, 2 November 2011). Di sisi lain Ketua Pengadilan Negeri yang sekaligus Ketua Pengadilan Tipikor Samarinda menanggapi lain, menurutnya, para hakim yang menangani perkara tipikor sudah menjalankan sesuai aturan yang ada, kalau memang terbukti, dihukum. kalau tidak terbukti dibebaskan. Kalau terbukti tapi bukan merupakan perbuatan tindak pidana dilepas. Itulah tugas pokok pengadilan (Majalah B Magazine edisi Desember 2011).

Atas semua tuduhan yang sinis terhadap vonis bebas oleh Pengadilan Tipikor Samarinda, apakah 
hal itu merupakan bentuk intervensi terhadap lembaga peradilan di Indonesia, padahal Indonesia adalah negara hukum, salah satu ciri negara hukum ialah ada suatu kemerdekaan hakim yang bebas dan tidak dapat dipengaruhi oleh kekuasaan ekskutif maupun kekuasaan legislatif, bahkan pihak atasan langsung dari hakim yang bersangkutan tidak mempunyai kewenangan untuk mempengaruhi apapun, "mendektekan" kehendaknya kepada hakim bawahan (Martiman Prodjohamidjojo, 1984: 1). Namun kebebasan hakim tidak harus diartikan bahwa hakim dapat melakukan tindakan sewenang-wenang terhadap suatu perkara yang diperiksanya, akan tetapi hakim tetap terikat pada hukum dan norma-norma yang ada.

Indonesia sebagai negara hukum, sudah selayaknya prinsip-prinsip suatu negara hukum harus dihormati dan dijunjung tinggi, bukan malah dilemahkan, salah satunya adalah prinsip adanya peradilan yang bebas dan tidak memihak. Prinsip ini dapat berjalan dengan baik, atau tidak tolok ukurnya dapat dilihat dari kemandirian badan-badan peradilan dalam menjalankan fungsi dan wewenangnya menegakkan hukum di bidang peradilan, maupun adanya aturan perundangundangan yang memberikan jaminan yuridis adanya kemerdekaan kekuasaan kehakiman, baik kemerdekaan lembaganya, kemerdekaan proses peradilannya dan kemerdekaan hakimnya.

Pengadilan tindak pidana korupsi merupakan bagian pelaksana kekuasaan kehakiman, karena berada di lingkungan peradilan umum, secara otomatis berada di bawah Mahkamah Agung Republik Indonesia, yang diberi wewenang khusus untuk memeriksa, mengadili, dan memutus perkara tindak pidana korupsi. Dalam sistem ketatanegaraan di Indonesia, pengadilan tindak pidana korupsi merupakan bagian dari kekuasaan yudikatif atau kekuasaan kehakiman, yang dijamin kebebasan dan kemandiriannya dalam UndangUndang, oleh karena itu masalah ini menarik untuk bahan kajian dan penelitian, apakah kemandirian pengadilan tindak pidana korupsi sudah sesuai dengan harapan ketatanegaraan Republik Indonesia.

Berdasarkan latar belakang yang diuraikan permasalahannya, iaalah Bagaimana kemandirian pengadilan tindak pidana korupsi dalam sistem ketatanegaraan di Indonesia?, dan mengapa masih ada pihak-pihak yang akan intervensi terhadap putusan pengadilan tindak pidana korupsi?

\section{B. Metode Penelitian}

Dalam penelitian ini menggunakan metode penelitian hukum normatif, yaitu penelitian hukum kepustakaan yang lazimnya disebut legal research atau legal research instruction (Soerjono Soekanto \& Sri Mamudji,2006, hal : 33-34, C.F.G. Sunaryati Hartono, 1994: 151). Pendekatan yang digunakan adalah pendekatan perundang-undangan (statute approach) yaitu dengan menelaah aturan hukum yang berlaku mengenai sistem ketata negaraan di Indonesia, khususnya yang mengatur tentang kemandirian pengadilan tindak pidana tipikor, menghimpun peraturan perundang-undangan merupakan data primer dan mengumpulkan teoriteori yang diperoleh dari bahan pustaka yang berkaitan dengan permasalah penelitian merupakan data sekunder, sedangkan data tersier diperoleh dari ensiklopedia hukum, kamus hukum, kamus bahasa dan lain sebagainya. Di samping itu dilakukan pula wawancara dengan beberapa hakim dan panitera di Pengadilan Tipikor Samarinda sebagai bahan pendukung dan sebagai bahan perbandingan. Analisis data yang dipergunakan adalah dengan menelaah Undang-Undang Dasar 1945 dan peraturan perundang-undangan lainnya yang berkaitan dengan kekuasaan kehakiman yang bebas dan mandiri. Bentuk penulisan dalam penelitian ini adalah diskriptif analisis, yaitu dengan membandingkan perundang-undangan yang ada dengan teori-teori hukum serta hasil wawancara sebagai bahan pendukung, kemudian hasilnya dipaparkan secara diskriptif analisis.

\section{Hasil Penelitian dan Pembahasan \\ 1. Kebebasan Kekuasaan Kehakiman di In- donesia}

Indonesia adalah negara hukum, hal itu seperti termuat di dalam Pasal 1 ayat (3) Undang Undang Dasar 1945 yang menyatakan :"Negara Indonesia adalah negara hukum." Salah satu ciri khas negara hukum adalah adanya peradilan yang bebas dan tidak memihak serta tidak dipengaruhi oleh suatu kekuasaan atau kekuatan apapun juga, sehingga dalam praktek sistem kenegaraan harus membagi kekuasaan negara agar tidak terjadi dominasi pemusatan kekuasaan negara yang berlebihan.

John Locke adalah seorang ahli filsafat negara dan hukum yang pertama-tama membedakan antara kekuasaan-kekuasaan sebagai fungsi-fungsi kenegaraan dengan menyebutnya tiga kekuasaan, yakni legislatif, eksekutif dan federatif. Kekuasaan yang tertinggi adalah kekuasaan legislatif, yakni kekuasaan pemerintah negara untuk membentuk Undang Undang. Kekuasaan kedua ialah kekuasaan ekskutif, yakni kekuasaan untuk melaksanakan Undang- 
Undang demi kepentingan umum. Kekuasaan ketiga adalah kekuasaan federatif adalah kekuasaan untuk mengambil putusan menyatakan perang dan mengadakan perdamaian, mengadakan kontrak dengan negara lain (Theo Huijbers, 1982: 83-84).

Kekuasaan yudikatif tidak dibicarakan dalam filsafatnya John Locke, anggapannya bahwa kekuasaan yudikatif sebagai bagian dari kekuasaan ekskutif, namun demikian kekuasaan yang ada harus ditentukan secara seimbang. Kekuasaan federatif sangat sulit dibedakan dengan kekuasaan ekskutif, sehingga sebenarnya tinggal dua kekuasaan. Kemudian Montesquieu yang terkenal dengan ajaran trias politica berjasa dengan menambahkan satu kekuasaan yaitu kekuasaan yudikatif, sebagai kekuasaan yang berbeda dari kekuasaan-kekuasaan lain. Seorang hakim harus berdaulat dalam bidangnya, artinya bahwa pimpinan negara tidak berhak untuk capur tangan dalam bidang ini, prinsip kedaulatan kekuasaan yudikatif sangat mendorong perkembangan negara hukum (Theo Huijbers, $1982: 87$ ).

Ketiga jenis kekuasaan tersebut, yaitu kekuasaan legislatif (kekuasaan membuat Undang Undang), kekuasaan ekskutif (kekuasaan menyelenggarakan UndangUndang), dan kekuasaan yudikatif (kekuasaan mengadili atas pelanggaran Undang-Undang) harus terpisah satu sama lainnya, baik mengenai tugas dan fungsi maupun mengenai alat perlengkapan (organ) yang menyelenggarakannya. Montesquieu juga berpendapat bahwa apabila kekuasaan negara itu dipisahkan secara tegas dan masing-masing kekuasaan itu dipegang oleh suatu badan yang berdiri sendiri, tentunya akan menghilangkan kemungkinan timbulnya tindakan yang sewenang-wenang dari seorang penguasa atau tegasnya memberikan kemungkinan terlaksananya sistem pemerintahan absolutisme (Suhino, 1993: 117).

Pelaksanaan teori trias politica di Indonesia dapat diamati melalu konstitusi yang berlaku di Indonesia yaitu UUD1945, ternyata secara eksplisit UUD1945 tidak pernah mencantumkan adanya teori trias politica, tetapi melihat kenyataan tentang pengaturan yang ada mengenai kekuasaan negara menunjukkan bahwa para perumus UUD 1945 sangat dipengaruhi oleh teori trias politica. Poros kekuasaan yang ada di Indonesia saat ini adalah kekuasaan legislatif dijalankan oleh MPR yang terdiri dari DPR dan DPD, kekuasaan ekskutif yaitu kekuasaan pemerintah

18 Yustisia Vol.1 No. 3 September -Desember 2012 dijalankan oleh Presiden, dan kekuasaan yudikatif dilaksanakan oleh MA, MK dan KY serta kekuasaan auditif dijalankan oleh Badan Pemeriksa keuangan (BPK). Melihat kenyataan yang ada di Indonesia secara eksplisit memang tidak menganut teori trias politica dalam arti pemisahan kekuasaan, tetapi sebenarnya UUD1945 sangat dipengaruhi oleh teori trias politica, namun poros-poros kekuasaan tersebut tidak diletakkan pada posisi yang terpisah secara mutlak, tetapi terjalin hubungan kerja sama dalam melaksanakan pemerintahan negara, sehingga dapat disimpulkan bahwa Indonesia menganut teori trias politika sebatas pembagian kekuasaan dan bukan pemisahan kekuasaan. Dalam uraian selanjutnya mengenai lembaga kekuasaan negara hanya akan dibahas mengenai kekuasaan yudikatif di Indonesia, khususnya mengenai pengadilan tindak pidana korupsi.

Kekuasaan yudikatif di Indonesia lazimnya disebut kekuasaan kehakiman. Pasal 24 ayat (1) UUD 1945 menyebutkan :"Kekuasaan kehakiman merupakan kekuasaan yang merdeka untuk menyelenggarakan peradilan guna menegakkan hukum dan keadilan. Kemudian Pasal 24 ayat (2) UUD 1945 menyebutkan :"Kekuasaan kehakiman dilakukan oleh sebuah Mahkamah Agung dan badan peradilan yang berada di bawahnya dalam lingkungan peradilan umum, lingkungan peradilan agama, lingkungan peradilan militer, lingkungan peradilan tata usaha negara, dan oleh sebuah Mahkamah Konstitusi." Kemudian ditegaskan pula dalam Undang Undang Nomor 48 Tahun 2009 tentang Kekuasaan Kehakiman.

Kekuasaan kehakiman yang merdeka dapat pula dijumpai dalam Pasal 10 The Universal Declaration of Human Rights, yang berbunyi :"Every one is intitled in full equality to a fair and public hearing by in independent and impartial tribunal in the determination of hisrights and obligations and of any criminal charge against him." (Setiap orang berhak dalam persamaan sepenuhnya didengarkan suaranya di muka umum dan secara adil oleh pengadilan yang merdeka dan tidak memihak, dalam hal menetapkan hak-hak dan kewajibannya dan dalam setiap tuntuan pidana yang ditujukan kepadanya) (Bambang Waluyo, 1992: 5).

Pengadilan tindak pidana korupsi walaupun tidak dicantumkan dalam Pasal 24 ayat (2) UUD 1945, namun dalam operasionalnya dapat dikategorikan bahwa pengadilan tindak pidana korupsi merupakan 
bagian dari pada kekuasaan kehakiman sebagaimana termuat dalam Pasal 24 ayat (1) dan (2) UUD 1945, karena keberadaan pengadilan tindak pidana korupsi berada menyatu dengan peradilan umum. Ketentuan tersebut diperkuat lagi dalam Pasal 31 Undang Undang Nomor 46 Tahun 2009, tentang pengadilan tindak pidana korupsi yang menyebutkan :"Pemeriksaan tingkat kasasi tindak pidana korupsi diperiksa dan diputus dalam waktu paling lama 120 (seratus dua puluh) hari kerja terhitung sejak tanggal berkas perkara diterima oleh Mahkamah Agung." Berarti pengadilan tindak pidana korupsi berada dibawah Mahkamah Agung juga.

IPasal 5 Undang Undang Nomor 46 Tahun 2009, tentang Pengadilan Tindak Pidana Korupsi menyebutkan :"Pengadilan tindak pidana korupsi merupakan satu-satunya pengadilan yang berwenang memeriksa, mengadili, dan memutus perkara tindak pidana korupsi." Ketentuan pasal tersebut mengandung makna sebuah kemandirian pengadilan tindak pidana korupsi. Kemandirian berasal dari kata mandiri menurut kamus bahasa Indonesia mandiri berarti dalam keadaan berdiri sendiri (Eko Hadi Wiyono, 2007: 385), artinya bebas dan merdeka, berdiri sendiri, terlepas dari pengaruh lain. Dengan demikian arti kemandirian adalah kebebasan atau kemerdekaan atau berdiri sendiri dan tidak terpengaruh dari pihak lain.

Maksud dari kemandirian adalah kebebasan atau kemerdekaan sesuatu dari berbagai pengaruh apapun dan siapapun. Pasal 10 Universal Declaration of Human Right menyebutkan bahwa kebebasan tersebut adalah kebebasan dari campur tangan badan ekskutif, legislatif ataupun masyarakat umum di dalam menjalankan tugasnya. Sebab hanya dengan asas kebebasan badan yudikatif itulah dapat diharapkan bahwa keputusan yang diambil oleh badan yudikatif dalam suatu perkara tidak akan memihak dan berat sebelah serta semata-mata berpedoman pada normanorma hukum dan keadilan maupun hati nurani hakim itu sendiri dengan tidak usah takut bahwa kedudukannya terancam (Miriam Budihardjo, 1996: 227-228).

Kebebasan kekuasaan kehakiman, yang penyelenggaraannya diserahkan kepada badan-badan peradilan, merupakan salah satu ciri khas dari negara hukum. Pada hakekatnya kebebasan ini merupakan sifat pembawaan dari pada setiap peradilan, hanya batas dan isi kebebasannya dipengaruhi oleh sistem pemerintahan, politik, ekonomi dan sebagainya (Sudikno Mertokusumo, 1982: 18). Pasal 1 ayat (1) Undang Undang Nomor 48 Tahun 2009 tentang Kekuasaan Kehakiman menyebutkan: "Kekuasaan Kehakiman adalah kekuasaan negara yang merdeka untuk menyelenggarakan peradilan guna menegakkan hukum dan keadilan berdasarkan Pancasila dan Undang Undang Dasar Negara Republik Indonesia Tahun 1945, demi terselenggaranya Negara Hukum Republik Indonesia."

Pengadilan tindak pidana korupsi merupakan bagian sistem peradilan di Indonesia yang menjalankan kekuasaan kehakiman atau kekuasaan yudikatif dalam sistem ketatanegaraan atau hukum tata negara. Hukum tata negara adalah hukum yang mengatur organisasi negara, hubungan alat perlengkapan negara susunan dan wewenangnya serta hak dan kewajibannya warga negara (Dasril Radjab, 2005: 6). Lebih lanjut Van Vollenhoven menyatakan bahwa :"Hukum Tata Negara adalah hukum yang mengatur semua masyarakat hukum tingkat atas sampai bawah, yang selanjutnya menentukan wilayah lingkungan rakyatnya, menentukan badanbadan yang berkuasa, berwenang dan fungsinya dalam lingkungan masyarakat hukum tersebut (Titik Triwulan Tutik, 2006: 2).

Badan-badan atau lembaga-lembaga yang menjalankan kekuasaan di Indonesia adalah lembaga legislatif (MPR yang terdiri dari DPR dan DPD), lembaga ekskutif (Pemerintahan dijalankan oleh Presiden), lembaga yudikatif (Kekuasaan kehakiman dijalankan oleh MA, MK, dan KY) serta lembaga auditif (dijalankan oleh BPK). Dalam uraian selanjutnya akan dibahas mengenai lembaga yudikatif yang dijalankan oleh Mahkamah Agung, khususnya pengadilan tindak pidana korupsi yang secara otomatis berada di bawah Mahkamah Agung dalam menjalankan fungsi ketatanegaraan sesuai sistem ketatanegaraan di Indonesia, yaitu mengenai kemandirian pengadilan tindak pidana korupsi dalam upaya menegakkan hukum dan keadilan.

\section{Kemandirian Pengadilan TIPIKOR dalam Sistem Ketatanegaraan di Indonesia.}

Sejak memproklamirkan kemerdekaannya Indonesia telah menetapkan dirinya sebagai negara hukum, hal itu dapat dilihat dalam penjelasan Undang Undang Dasar 1945 sebelum mengalami perubahan, yang menyatakan :"Negara Indonesia berdasar atas hukum (Rechtsstaat), tidak berdasar atas 
kekuasaan belaka (Machtsstaat). Kemudian dipertegas lagi dalam Pasal 1 ayat (3) Undang Undang Dasar 1945 setelah mengalami perubahan, yang menyatakan :"Negara Indonesia adalah negara hukum."

Pengertian negara hukum termuat dalam Pasal 4 huruf a dan penjelasannya Undang Undang Nomor 37 Tahun 2008, tentang Ombudsman menyebutkan :"Yang dimaksud negara hukum adalah negara yang dalam segala aspek kehidupan bermasyarakat, bergangsa dan bernegara termasuk dalam penyelenggaraan pemerintah harus berdasarkan hukum dan asas-asas umum pemerintahan yang baik dan bertujuan meningkatkan kehidupan demokrasi yang sejahtera, berkeadilan dan bertanggung jawab."

Namun demikian, jika ingin membuktikan suatu negara disebut negara hukum, maka harus diketahui lebih dahulu kriteria dan ciriciri sebagai negara hukum, dengan mengetahui ciri-ciri tersebut kemudian dapatlah dinyatakan negara tersebut sebagai negara hukum (Muchsin, 2010: 41). Suatu negara hukum pada prinsipnya menghendaki segala tindakan dan perbuatan penguasa selalu mempunyai dasar hukum yang jelas, baik secara tertulis maupun tidak tertulis, di samping itu pada negara hukum terdapat beberapa ciri khas, yaitu (Bambang Sutiyoso, 2005: 1):

a. pengakuan dan perlindungan hak-hak asasi manusia, yang mengandung persamaan dalam politik, hukum, sosial, ekonomi dan kebudayaan;

b. peradilan yang bebas dan tidak memihak serta tidak dipengaruhi oleh suatu kekuasaan atau kekuatan apapun; dan

c. legalitas dalam arti hukum dalam segala bentuknya.

Konsepsi negara hukum semula berasal dari istilah rechstaat yang mulai populer di Eropa (Belanda, Perancis, Belgia dsb) yang bertumpu atas sistem hukum Kontinental disebut civil law, kemudian juga berkembang istilah the rule of law yang populer di negaranegara Anglo-Saxon (Inggris, Amerika) yang bertumpu atas sistem hukum yang disebut common law. Adapun corak negara hukum di Indonesia sepertinya mengikuti sistem rechstaat, hal ini disebabkan karena Indonesia pernah dijajah Belanda cukup lama sehingga hukumnya pun sangat berpengaruh untuk diikutinya.

Ciri-ciri rechstaat adalah adanya pengakuan dan perlindungan terhadap hak-hak asasi manusia yang bertumpu atas prinsip kebebasan dan persamaan; Adanya Undang Undang Dasar yang memberikan jaminan konstitusinal terhadap asas kebebasan dan persamaan. Adanya pembagian kekuasaan untuk menghindari penumpukan kekuasaan dalam satu tangan yang sangat cenderung pada penyalahgunaan kekuasaan yang berarti pemerkosaan terhadap kebebasan dan persamaan (Ni'matul Huda, 2005: 74).

Paham negara hukum tidak dapat dipisahkan dari paham kerakyatan (demokrasi), sebab pada akhirnya hukum yang mangatur dan membatasi kekuasaan negara atau pemerintahan diartikan sebagai hukum yang dibuat atas dasar kekuasaan atau kedaulatan rakyat. Atas dasar demokrasi, negara hukum (rechstaat) dikatakan sebagai negara kepercayaan timbal balik (de staat van het wederzeijds vertrouwen), yaitu kepercayaan dari rakyat pendukungnya bahwa kekuasaan yang diberikan tidak akan disalah gunakan dan kepercayaan dari penguasa bahwa dalam batas kekuasaannya dia mengharapkan keputusan dari rakyat pendukungnya (Ni'matul Huda, 2005: 245-246).

Untuk melaksanakan nilai-nilai demokrasi, perlu diselenggarakan beberapa lembaga , yaitu (Ni'matul Huda, 2005: 245):

a. Pemerintahan yang bertanggung jawab;

b. Suatu Dewan Perwakilan Rakyat yang mewakili golongan-golongan dan kepentingan-kepentingan dalam masyarakat dan yang dipilih dengan pemilihan umum yang bebas dan rahasia dan atas dasar sekurang-kurangnya dua calon untuk setiap kursi;

c. Suatu organisasi politik yang mencakup satu atau lebih partai politik;

d. Pers dan media masa yang bebas untuk menyatakan pendapat; dan

e. Sistem peradilan yang bebas untuk menjamin hak-hak asasi dan mempertahankan keadilan

Bentuk negara demokrasi di Indonesia termuat dalam Pasal 1 ayat (2) UUD 1945 yang menyatakan :"Kedaulatan berada di tangan rakyat dan dilaksanakan menurut Undang Undang Dasar." Bentuk negara hukum termuat dalam Pasal 1 ayat (3) UUD 1945 yang menyatakan :"Negara Indonesia adalah negara hukum." Sedangkan pilar-pilar yang menyelenggarakan kekuasaan negara, dalam sistem ketatanegaraan di Indonesia telah diatur secara rinci dalam UUD 1945, di antaranya adalah:

Kemandirian Pengadilan Tindak Pidana ... 
Pertama: kekuasaan legislatip, termuat dalam Pasal 2 ayat (1) UUD 1945 yang menyatakan:"Majelis Permusyawaratan Rakyat terdiri atas anggota Dewan Perwakilan Rakyat dan anggota Dewan Perwakilan Daerah yang dipilih melalui pemilihan umum dan diatur lembih lanjut dengan Undang-Undang.:

Kedua: kekuasaan ekskutip, termuat dalam Pasal 4 ayat (1) UUD 1945 yang menyatakan:"Presiden Republik Indonesia memegang kekuasaan pemerintah menurut Undang Undang Dasar."

Ketiga: kekuasaan yudikatip, termuat dalam Pasal 24 ayat (2) UUD 1945 yang menyatakan: "Kekuasaan kehakiman dilaksanakan oleh sebuah Mahkamah Agung dan badan peradilan yang berada di lingkungan peradlan umum, lingkungan peradilan agama, lingkungan peradilan militer, lingkungan peradilan tata usaha negara, dan oleh sebuah Mahkamah Konstitusi."

Keempat: Kekuasaan auditif, termuat dalam Pasal 23 ayat (1) UUD 1945 yang menyatakan :"Untuk memeriksa pengelolaan keuangan negara diadakan satu Badan Pemeriksa Keuangan yang bebas dan mandiri."

Struktur kelembagaan kekuasaan negara di Indonesia, jika diperhatikan hampir mirip dengan teori trias politica yang dikembangkan oleh Montesquiue, namun ajaran trias politica tidak mencantumkan kekuasaan auditif, sedangkan di Indonesia kekuasaan auditif yang ada sebenarnya bukan merupakan bagian dari pada kekuasaan negara melainkan kekuasaan yang independen, yaitu kekuasaan khusus dalam bidang pemeriksaan keuangan negara yang dilakukan oleh Badan Pemeriksa Keuangan (BPK). Pembahasan selanjutnya akan terfokus pada salah satu kekuasaan yang menjadi topik dalam penelitian ini, yaitu kekuasaan yudikatif atau kekuasaan Kehakiman, khususnya kekuasaan yang ada pada pengadilan tindak pidana korupsi.

Kekuasaan kehakiman selain telah diatur dalam Pasal 24 ayat (1) dan (2) Undang Undang Dasar 1945, ditegaskan pula dalam Pasal 1 ayat (1) Undang Undang Nomor 48 Tahun 2009 tentang Kekuasaan Kehakiman yang menyatakan: "Kekuasaan kehakiman adalah kekuasaan negara yang merdeka untuk menyelenggarakan peradilan guna menegakkan hukum dan keadilan berdasarkan Pancasila dan Undang Undang Dasar Negara Republik Indonesia Tahun 1945, demi terselenggaranya Negara Hukum Republik
Indonesia. Kekuasaan kehakiman di Indonesia dilakukan oleh Mahkamah Agung dan badan peradilan di bawahnya, sedangkan yang menjalankan tugas kekuasaan kehakiman itu adalah para hakim.

Pasal 1 ayat (5) Undang Undang Nomor 48 Tahun 2009, tentang Kekuasaan Kehakiman menyatakan bahwa :"Hakim adalah hakim pada Mahkamah Agung dan hakim pada badan peradilan yang berada dibawahnya dalam lingkungan peradilan umum, lingkungan peradilan agama, lingkungan peradilan militer, lingkungan peradilan tata usaha negara, dan hakim pada peradilan khusus yang berada dalam lingkungan peradilan tersebut." Kemudian Pasal 3 ayat (1) menyebutkan bahwa :"Dalam menjalankan tugasnya, hakim dan hakim konstitusi wajib menjaga kemandirian peradilan.

Kemandirian kekuasaan kehakiman, khususnya pengadilan tindak pidana korupsi, dapat dibedakan menjadi tiga macam, yaitu kemadirian lembaganya, kemadirian proses peradilannya dan kemandirian hakimnya. Berikut ini akan diuraikan secara singkat tentang tipe ketiga macam kemadirian tersebut.

Pertama, Kemandirian lembaganya, yaitu pengadilan tindak pidana korupsi. Secara normatif kemandirian pengadilan tipikor telah mempunyai lembaga yang dijamin oleh konstitusi atau UUD 1945 dan Undang Undang Nomor 46 Tahun 2009 tentang Pengadilan Tindak Pidana Korupsi merupakan pengadilan khusus yang berada di lingkungan peradilan umum. Diuraikan dalam Pasal 5 Undang Undang Tindak Pidana Korupsi, yang menyatakan :"Pengadilan tindak pidana korupsi merupakan satu-satunya pengadilan yang berwenang memeriksa, mengadili, dan memutus perkara tindak pidana korupsi." Kewenangan lembaga pengadilan tindak pidana korupsi merupakan lembaga yang independen dan tidak ada ketergantungan dengan lembaga lainnya.

Kedua, Kemandirian proses peradilan. Proses peradilan pada pengadilan tindak pidana korupsi dilakukan berdasarkan hukum acara pidana yang berlaku, kecuali ditentukan lain dalam Undang-Undang Tindak Pidana Korupsi. Ketentuan lain yang dimaksud misalnya hakim yang mengadili terdiri hakim karier dan hakim ad hoc dengan komposisi yang sudah ditentukan. Waktu pemeriksaan perkara ditentukan, yaitu 120 hari (seratus dua puluh hari) kerja pada pengadilan tingkat 
pertama, 60 hari (enam puluh hari) kerja pada pengadilan tingkat banding dan 120 hari (seratus dua puluh hari) kerja pada pemeriksaan tingkat kasasi, serta 60 (enam puluh hari) kerja dalam hal dimintakan peninjauan kembali. Atas segala pengaturan sedemikian rupa dalam proses peradilan, diharapkan tidak ada pihak-pihak yang dapat intervensi terhadap jalannya proses peradilan tindak pidana korupsi.

Ketiga, Kemandirian hakimnya. Kemandirian hakim di sini sangat menentukan karena hakim merupakan tenaga inti dalam penegakan hukum tindak pidana korupsi, sedangkan parameter kemandiriannya adalah dalam memeriksa perkara korupsi dapat dilihat dari kemampuan dan ketahannya dalam menjaga integritas moral dan komitmen kebebasan profesinya dalam nejalankan tugas dan wewenangnya dari adanya campur tangan pihak lain. Jika hakimnya terpengaruh oleh campur tangan pihak lain, baik itu ekskutif, legislatif, maupun atasannya langsung bahkan dari berbagai komentar masyarakat, maka hal itu menunjukkan bahwa hakimnya kurang mandiri, tetapi jika yang terjadi sebaliknya, maka hakim tersebut telah memegang teguh kemandiriannya.

Kemandirian atau kebebasan hakim merupakan asas yang sifatnya universal, berarti bahwa dalam melaksanakan peradilan, hakim itu pada dasarnya bebas, yaitu bebas dalam memeriksa dan mengadili perkara dan bebas dari campur tangan atau turun tangan kekuasaan ekstra yudisial. Pada dasarnya dalam memeriksa dan mengadili, hakim bebas untuk menentukan sendiri cara-cara memeriksa dan mengadili berdasarkan hukum acara yang berlaku. Pada dasarnya tidak ada pihak-pihak, baik atasan hakim yang bersangkutan maupun pihak ekstra yudisial yang boleh mencampuri jalannya sidang peradilan (Bambang Sutiyoso, 2005: 51). Namun demikian secara mikro tugas hakim dibatasi oleh Pancasila dan UUD 1945 serta kode etik perilaku hakim.

Dalam sistem hukum di Indonesia, Pancasila dijadikan sebagai norma dasar atau grund norm, sehingga Pancasila bertugas sebagai kaidah dasar, yaitu kaidah atau norma yang menjadi dasar berlakunya dan legalitas hukum positif di Indonesia, baik hukum yang berupa Undang-Undang maupun yurisprudensi (putusan hakim). Pancasila mengajarkan kepada bangsa Indonesia mengenai cita-cita kemerdekaan individu dalam arti hak asasi manusia, disamping itu Pancasila tersusun secara hierarkis piramida, yang bulat dan utuh, artinya bahwa sila yang ada dibawahnya tidak boleh bertentangan dengan sila diatasnya, sedangkan sila yang paling atas adalah KeTuhanan Yang maha Esa. Demikan juga halnya putusan pengadilan harus mencantumkan "demi keadilan berdasarkan Ke-Tuhanan Yang Maha Esa."

Kode etik dan perilaku hakim termuat dalam keputusan bersama Ketua Mahkamah Agung Republik Indonesia dan Ketua Komisi Yudisial Republik Indonesia, tentang Kode Etik dan Pedoman Perilaku Hakim, pada angka 4 dinyatakan bahwa hakim harus bersikap mandiri, dalam penerapannya diuraikan sebagai berikut.

a. hakim harus menjalankan fungsi peradilan secara mandiri dan bebas dari pengaruh, tekanan, ancaman atau bujukan, baik yang bersifat langsung maupun tidak langsung dari pihak manapun;

b. hakim wajib bebas dari hubungan yang tidak patut dengan lembaga ekskutif maupun legislatif serta kelompok lain yang berpotensi mengancam kemandirian (independensi) Hakim dan Badan Peradilan; dan

c. hakim wajib berperilaku mandiri guna memperkuat kepercayaan masyarakat terhadap Badan Peradilan.

\section{Intervensi Putusan Pengadilan TIPIKOR}

Kemandirian pengadilan tindak pidana korupsi, dapat dilihat dari beberapa indikator, di antaranya adalah kemandirian lembaganya, kemandirian proses peradilannya dan kemandirian hakimnya. Dari indikator-indikator tersebut dapat dipastikan bahwa Pengadilan Tindak Pidana Korupsi telah dijamin secara konstitusional dalam Pasal 24 ayat (2) UUD 1945, kemudian dikuatkan dengan Undang Undang Nomor 48 Tahun 2009, tentang Kekuasaan Kehakiman dan Undang-Undang Nomor 46 Tahun 2009, tentang Pengadilan Tindak Pidana Korupsi (Tipikor), sehingga sudah tidak ada kekuatan intervensi dari lembaga negara lainnya.

Indikator berikutnya adalah kemandirian proses peradilan tindak pidana korupsi harus dilakukan secara terbuka atau di muka umum, demikian dinyatakan dalam Pasal 13 ayat (1), (2) dan (3) Undang Undang Nomor 48 Tahun 2009, tentang Kekuasaan Kehakiman. Hal tersebut mempunyai indikasi kuat bahwa setiap 
sidang harus dapat diketahui oleh publik dan bukan merupakan sidang yang dirahasiakan, kecuali memang ditentukan lain oleh Undang Undang. Keterbukaan dalam sidang itu secara fair menunjukkan kepada publik bahwa sidang yang dilakukan tidak berat sebelah, atau memihak salah satu pihak sehingga kebenaran dan keadilan benar-benar dapat ditegakkan, terhadap hal ini juga sulit adanya intervensi dari pihak lain untuk dapat masuk dalam proses peradilannya

Dasar atau alasan yang menjadi basis putusan hakim harus dinyatakan secara terbuka, dengan mempertimbangkan segala fakta yang terungkap dalam persidangan, yaitu mengenani fakta hukum yang diketemukan, pertimbangan mengenai keterlibatan pelaku atau kesalahan yang dilakukan terdakwa, pertimbangan tentang keadaan terdakwa yang diperlukan dalam mengambil sebuah putusan, serta mengungkapkan penemuan hukum yang diyakini oleh hakim dalam memutuskan perkara, itulah indikator kemandirian hakimnya.

Putusan pengadilan tipikor pada intinya hanya ada tiga, yaitu pertama : menghukum terdakwa jika diyakini bahwa terdakwa terbukti bersalah, kedua : membebaskan terdakwa karena walaupun terbukti ada tindak pidana tetapi tidak terbukti bahwa bukan terdakwa pelakunya, dan ketiga : membebaskan terdawa dari segala hukuman, karena tidak terbukti ada tindak pidana. Putusan hakim dalam perkara korupsi biasanya sering dijumpai berbagai kritik terhadap lembaga peradilan maupun hakimnya, apalagi jika perkara korupsi itu bebas, maka segala tuduhan yang begitu tajam ditujukan kepada hakim yang memutus perkara tersebut.

Segala kritikan tajam terhadap putusan hakim kiranya sudah menjadi rahasia umum, karena telah dimuat dalam berbagai mas media baik cetak maupun tertulis. Kritikan-kritikan tersebut seolah hakim tidak boleh menegakkan kebenaran material yang terungkap dalam persidangan, anggapannya adalah bahwa semua terdakwa yang diadili di pengadilan tipikor harus dihukum tanpa mempertimbangkan kebenaran materiil yang terungkap dalam persidangan. Namun sebenarnya semua kritik itu jika disampaikan secara sopan dan ilmiah tentu dapat diterima dengan baik, sebagai suatu diskursus kebebasan mengemukakan pendapat dimuka umum, sehingga berbagai kritik tersebut dapat dijadikan sebagai koreksi dan instropeksi diri para penegak hukum.

Hakim adalah manusia biasa, bukan Tuhan, oleh karenanya tidak mungkin akan memberikan pertimbangan dan putusan secara absolut adil, juga hakim sebagai manusia yang tidak pernah terhindar dari perbuatan salah dan dosa, semua kritikan itu mungkin saja terjadi karena kelalaian ataupun disengaja, karena sebagai manusia biasa, hakim juga mempunyai sifat dan nafsu yang sama seperti manusia lainnya. Jika yang dituduhkan itu benar adanya adalah suatu hal yang paradoks dan pantas untuk disoroti secara tajam pula, maka kondisi seperti itu pasti tidak mengherankan kalau sering kita dengar istilah-istilah "peradilan kelabu", "mafia peradilan", "kolusi peradilan", dan sebagainya yang menurunkan citra lembaga peradilan.

Biasanya godaan-godaan yang mempengaruhi hakim itu sebenarnya justru datang dari masyarakat pencari keadilan, dengan menjanjikan sesuatu untuk membebaskan kasusnya. Godaan-godaan itu bermacam-macam caranya, dapat melalui calo, penuntut umum, dan bahkan secara langsung menghubungi hakimnya. Semula sang hakim tidak peduli dengan sebagala permintaan dan janji yang ditawarkan, ada yang tetap pada pendiriannya dan tidak mau terpengaruh, tetapi terkandang ada juga yang tergoda, hal ini dikembalikan karena sang hakim adalah juga manusia yang mempunyai nafsu dan kebutuhan seperti manusia lainnya, tetapi anehnya jika hal itu terungkap justru hakimnyalah yang mendapatkan kritikan tajam dari masyarakat, sedangkan masyarakat yang memulainya tidak pernah tersentuh dengan kritikan.

Semua kritik yang disapaikan hendaknya menyertakan data sebagai pendukung kritikan tersebut, tetapi sebaliknya jika kritikan itu tanpa disertai data dan bukti yang kuat, misalnya tuduhan terhadap penyuapan hakim dalam suatu perkara korupsi tertentu, bahkan disampaikan secara arogan dan ditulis pada media masa, seolah-olah hendak mengintervensi putusan hakim, tentu saja hal itu sudah merupkan fitnah yang tidak ada dasarnya sama sekali, dan sudah mengarah pada penghinaan lembaga peradilan (contempt of court). Di luar negeri menghina pengadilan atau contempt of court merupakan tindak pidana yang serius dan orang bisa ditahan dan diadili dipengadilan tersebut (Gunarto Suhardi, 2006 : 44). Bentuk penghinaan ini ada bermacam-macam, dapat berbentuk tindakan secara langsung atau berbentuk pernyataan, sedangkan pernyataan tersebut dapat secara langsung oral dan bisa juga berbentuk pernyataan publik yang dengan sendirinya dilakukan dan dikutip oleh mas 
media secara luas. Pernyataan yang dilakukan baik dengan perbuatan maupun dengan katakata yang menghina tentu saja telah melanggar hak asasi para hakim bahkan melanggar hak asasi publik secara menyeluruh, di samping itu pernyataan-pernyataan tersebut telah melanggar konstitusi,atau UUD 1945, karena secara konstitusional kebebasan hakim dijamin dalam UUD1945.

Pernyataan dan tanggapan berupa kritikan tajam yang sudah mengarah pada tuduhantuduhan dan sebagainya itu biasanya mereka tidak mengetahui secara persis fakta-fakta yang terungkap dalam persidangan, karena hakim dalam memutus perkara harus berdasar pada fakta-fakta yang terungkap dalam persidangan, di samping itu kurangnya pemahaman bahwa semua perkara yang diajukan dalam persidangan tidak harus dihukum jika tidak terbukti bersalah, dan hakim harus menghukum jika terbukti bersalah, karena namanya lembaga peradilan bukan lembaga penghukuman.

Tanggapan dan pernyataan begitu tajam ditujukan pada hakim yang menangani perkara korupsi sudah menuju pada bentuk-bentuk intervensi perorangan dan bahkan tekanan maupun tuduhan yang tidak berdasar sama sekali, tentu saja hal itu dilakukan sebenarnya merupakan sebuah empati terhadap perbuatan korupsi yang merupakan kejahatan luar biasa (extra ordinary crime), tetapi mereka yang mengeluarkan pernyataan berupa kritik itu tidak menyadari bahwa kebebasan hakim dijamin secara konstitusional dalam UUD 1945, namun demikian kebebasan hakim tetap berdasarkan norma-norma hukum yang beralku, bukan bebas semaunya sendiri tanpa dasar yang kuat.

\section{Simpulan}

Berdasarkan hasil penelitian dan pembahasan disimpulkan sebagai berikut.

1. Kemandirian pengadilan tindak pidana korupsi indikatornya dapat dilihat dari kemandirian lembaganya, proses peradilannya hakimnya. Kemadirian lembaga peradilan tindak pidana korupsi keberadaannya sudah dijamin secara konstitusional dalam UUD 1945 dan perundangundangan lainnya yang tidak dapat dicampuri oleh lembaga Negara lainnya. Kemandirian proses peradilan perkara korupsi telah diatur dalam hukum acara yang berlaku dan UU tipikor. Kemandirian hakimnya inilah yang banyak menimbulkan kritikan, oleh karena itu hakim harus tunduk pada kode etik yang telah ditentukan oleh Mahkamah Agung dan Komisi Yudisial dan harus memegang teguh keyakinannya untuk menggali keadilan berdasarkan Ke-Tuhanan yang Maha Esa.

2. Lembaga maupun proses peradilan kiranya sudah tidak dapat lagi diintervensi oleh lembaga negara lain maupun pihak lain, tetapi intervensi banyak ditujukan kepada para hakim yang menangani perkara korupsi berupa tanggapan, kritikan bahkan celaan yang sudah mengarah pada penghinaan pengadilan (contempt of court). Tanggapan tersebut disampaikan karena tidak mengetahui persis hal yang telah terungkap dalam persidangan, serta kurangnya memahami bahwa pengadilan itu tidak harus selalu menghukum terhadap perkaya yang ditanganinya, jika terbukti tidak bersalah, karena bukan lembaga penghukuman tetapi lembaga peradilan, yaitu mengadili perkara yang diajukan dalam persidangan, agar tercipta rasa keadilan.

\section{E. Saran}

Berdasarkan simpulan, maka disarankan sebagai berikut.

1. Kepada Komisi Yudisial disarankan, seleksi hakim yang menangani kasus korupsi agar diperketat lagi, dan benar-benar memilih hakim yang berintegritas tinggi, tidak mudah tergoda yang mengamcam dirinya. Selain hal itu, pengawasan terhadap hakim agar lebih ditingkatkan lagi, dan menindak tegas terhadap hakim yang terbukti melakukan pelanggaran, sehingga dapat menurunkan martabat peradilan.

2. Kepada para wartawan cetak maupun elektronik agar memuat berita-berita kasus korupsi secara netral, tidak tendensi dan tidak memihak manapun, sehingga tidak menyesatkan masyarakat yang membacanya. 


\section{Daftar Pustaka}

Bambang Sutiyoso. 2005. Aspek-Aspek Perkembangan Kekuasaan Kehakiman Di Indonesia. Yogyakarta: UII Press.

Bambang Waluyo. 1992. Implementasi Kekuasaan Kehakiman Republik Indonesia. Jakarta: Sinar Grafika

C.F.G. Sunaryati Hartono. 1994. Penelitian Hukum di Indonesia Pada Akhir Abad Ke-20. Bandung: Alumni Dasril Radjab. 2005. Hukum Tata Negara Indonesia. Jakarta: Rineka Cipta.

Eko Hadi Wiyono. 2007. Kamus Bahasa Indonesia Lengkap. Jakarta: Pelanta.

Gunarto Suhardi. 2006. Menegakkan kemandirian Yudisial. Yogyakarta: Universitas Atma Jaya.

M. Agus Santoso. 2011. "Dampak penjatuhan pidana korupsi bagi pegawai Negeri yang sedang menjalankan tugas Administrasi Negara". Jurnal Administrator Borneo, PKP2A LAN Samarinda, Vol. 7, No. 2, Tahun 2011.

Martiman Prodjohamidjojo. 1984. Kemerdekaan Hakim, keputusan bebas murni (arti dan makna). Jakarta: Simplex.

Miriam Budihardjo. 1996. Dasar-Dasar Pemikiran Ilmu Politik. Jakarta: Gramedia Pustaka Utama.

Muchsin. 2010. Kekuasaan Kehakiman Yang Merdeka (Independence Judicary).. Surabaya: UNTAG Press

Ni'matul Huda. 2005. Hukum Tata Negara Indonesia. Jakarta: Raja Grafindo Perkasa.

Soehino. 1993. IImu Negara. Yogyakarta: Liberty Theo Huijbers. 1982. Filsafat Hukum dalam Lintasan Sejarah. Yogyakarta: Kanisius.

Soerjono Soekanto dan Sri Mamudji. 2006. Penelitian Hukum Normatif Suatu Tinjauan Singkat. Jakarta: Raja Grafindo Persada.

Sudikno Mertokusumo 1998. "Revitalisasi dan Fungsionalisasi Lembaga Peradilan”. Makalah. Disampaikan pada Diskusi Usulan GBHN 98 di Fakultas Hukum UII, Yogyakarta, 15 Juli 1998.

Titik Triwulan Tutik. 2006. Pokok-Pokok Hukum Tata Negara. Jakarta: Prestasi Pustaka Plubliser. 